This Journal is available in Telkom University online Journals

Jurnal Manajemen Indonesia

\title{
Priority Policies And Program Of UIN Sunan Gunung Djati Bandung Toward World Class University
}

\author{
D. Jamaluddin ${ }^{1 *}$, T. Priatna1, K. Umam ${ }^{2}$, E. Paujiah ${ }^{3}$, D. Miharja ${ }^{4}$ and A. Andi Rahman ${ }^{5}$ \\ 1,2,3,4,5 UIN Sunan Gunung Djati Bandung, Jl. AH. Nasution, No. 105, Cibiru, Bandung, Indonesia
}

\begin{abstract}
The rising global competition makes State Islamic University (UIN) Sunan Gunung Djati Bandung, to increase the quality of its institution toward World Class University. This study aims to describe the university policies and the recommended top priority programs for the next five years (2019-2023). This study was conducted in 2019 on the campus. The study used descriptive analysis and the result was analyzed based on Quacquarelly Symonds $(Q S)$ ranking. The data was gathered using a forum group discussion and field study. The field study was in the form of benchmarking on several universities in Indonesia. The result showed that the growth rate was constant, and it can be meassured that UIN Sunan Gunung Djati Bandung will become World Class University by 2029; It will have score 23 and will be in the 500 QS Asia World University ranking. Through annual programs and targets, UIN Sunan Gunung Djati Bandung can achieve its goals to be a world class university.
\end{abstract}

Keywords-Higher Educational Institution; QS Ranking; UIN Sunan Gunung Djati; World Class University

\begin{abstract}
Abstrak
Meningkatnya daya saing global yang dihadapi perguruan tinggi di Indonesia menjadikan Universitas Islam Negeri Sunan Gunung Djati Bandung, Jawa Barat lebih fokus lagi dalam meningkatkan kualitas lembaga menuju universitas kelas dunia (World Class University). Penelitian ini bertujuan untuk mendeskripsikan kebijkan UIN SGD Bandung beserta rekomendasi program prioritasnya untuk periode lima tahun kedepan (2019-2023). Penelitian ini dilakukan pada tahun 2019 di Kampus UIN Sunan Gunung Djati Bandung. Metode yang digunakan adalah metode deskriptif analisis yang kemudian hasilnya dianalisis berdasarkan indikator Quacquarelli Symonds (QS) Rangking. Teknik pengumpulan data yang dilakukan adalah melalui teknik Forum Group Discussion (FGD) dan studi lapangan berupa bencmarking ke beberapa universitas di Indonesia. Hasil penelitian menunjukan bahwa jika diasumsikan laju pertumbuhan dengan skor konstan 2, maka diprediksi bahwa UIN Sunan Gunung Djati Bandung untuk menjadi World Class University dengan memenuhi enam kriteria QS dan skor total sekitar 23 (urutan 500 QS Asia World University) dapat dicapai pada tahun 2029. Melalui rekomendasi program dan target setiap tahunnya diharapkan UIN Sunan Gunung Djati Bandung dapat mencapai tujuannya menjadi universitas dengan kualitas World Class University.
\end{abstract}

Kata kunci-Institusi Pendidikan Tinggi; QS Rangking; UIN Sunan Gunung Djati; Universitas Kelas Dunia

\section{INTRODUCTION}

The rapid growth and the development of the global economy enable a new trend in the education industry. Many universities aim to achieve world-class universities that can be recognized internationally. Nowadays, universities are struggling to become world-class globally (Shin \& Kehm, 2012) and instead, Yudkevich et al. (2015) state that global university rankings like "the Olympic games of higher education". Indeed, some educational institutions claimed themselves as a world-class university (Altbach, 2004; Deem et al., 2008 that will allow some effects on the meaning of university (Byun et al., 2013). However, there is no sufficient confirmation on that claim. That is to say, a proper comprehension of world-class university is needed. A worldclass university itself is a university ranked among the top and the most prestigious academic institutions globally 
(Altbach \& Balán, 2007). Writing in a similar vein, Aula \& Tienari (2011) imply that a world-class university is a university with great honor and reputation internationally. Also, Ramaprasad (2011) defines the term as an institution ecology with extremely differentiated but firmly integrated visions. Hence, it has become the top goal of universities around the world, including in Indonesia.

Studying priority policies and programs is one of the important steps that can be taken toward worldclass universities. In particular, the study about priority and policies of institutions can describe the national or government power (see Alperin, 2013) via science and education in a country (Yang \& Welch, 2012). Furthermore, according to Tayeb et al. (2016), studying priority policies and programs at King Abdulaziz University (KAU) shows academic and institution strengths. To achieve this, KAU conducted mapping on several critical components to achieve World Class University status (Suyanti, 2011). Universities used different strategies to achieve internationalization. Several universities in Indonesia, like Universitas Indonesia and Institut Pertanian Bogor, carried out internationalization strategies through research policies. Meanwhile, Muhammadiyah University Semarang undertook website optimization (Supradono, 2010). Other universities also must have certain strategies and plan to develop their institution toward world class university further.

World Class University can be achieved using three main factors. First, it must have faculty members and students that have a high concentration of altitude. Second, it must have abundant resources, and lastly, it must have good governance (Salmi, 2009; Margison 2011). These three key factors will integrate and create three basic aspects that become indicators of a world-class status. Those factors are graduates who have high admission in the community, the quality of the research outputs, and transfer of high access technology to various information.

Each university will have different top programs and policies to accomplish these targets. Undeniably, the strategy carried out by UIN Bandung can be observed by the priority policies and programs set out by the institution. Thus, this study was aimed to describe the priority policies and programs implemented by the university to reach the goal. Wieczorek and Hekkert (2012) state that systemic steps are needed to achieve certain goals. Therefore, the results of this study are expected to ensure systemic and measurable steps of UIN Sunan Gunung Djati Bandung in achieving of the world class university indicators.

\section{RESEARCH METHOD}

The study was conducted in UIN Sunan Gunung Djati Bandung in 2019. It used a qualitative approach to provide deep meaning to the data collected. The study chose this approach since instead of testing a hypothesis, it aimed to describe data, facts, and conditions or tendencies that were present instead. It also analyzed and predicted what must be carried out to achieve the expected condition in the future.

The study used the descriptive method to describe and interpret an object. In this study, the author tried to describe the objective condition of UIN Sunan Gunung Djati Bandung. After describing the institution, the author then set out the policies that will lead to the institution's target toward world class university. All information that is needed for this study was collected from different sources (primary and secondary data). Primary data were obtained from the object under study directly. The data was taken from researchers' direct observation methods as part of the strategic planning team of UIN Sunan Gunung Djati Bandung and interviews via a group discussion forum. While secondary sources are obtained from various sources, including a documentation (i.e. books, reports , and information from parties related to the material being studied). At the same time, secondary sources were achieved from various sources, including documentation. Information from stakeholders, documents, policies, and institutions.

The data analysis method used in this research is descriptive analysis; a descriptive way of analyzing data on the research variables used. Data analysis was carried out with several stages, namely data reduction, data display, inference, and verification. The analysis method of UIN Sunan Gunung Djati Bandung readiness toward world class university is to compare it with QS World University Ranking indicators. These indicators are academic, employment, students, and international component. The four indicators are the results of content validation relating to the substance of world class university indicators. The substance of the predetermined contents was confirmed to policymakers about the extent of UIN Sunan Gunung Djati Bandung availability to achieve the measurable targets. The result of the analysis of the four factors was then described as the main finding of this study.

Furthermore, the components described consisted of the objective condition of UIN Sunan Gunung Djati Bandung and its projection. It also contained recommended priority policies and programs for UIN Sunan Gunung 
Djati Bandung for the period 2019-2023. After formulating the indicators from World Class University, yearly programs are then recommended for priority programs.

\section{RESULT AND DISCUSSION}

\section{A. The current condition and the projection}

The current condition of Sunan Gunung Djati Bandung in 2019 can be observed from the Rector Performance Agreement in 2019. Table 1 figures out the data for this agreement. Also, the programs presented in Table 1 were supported by the budget from the Ministry of Religious Affairs. 60\% of the budget was used for upgrading access, quality, relevance, and competitiveness of Islamic Higher Education. Meanwhile, $40 \%$ of the budget was for supportive programs of Education Management, and other technical tasks of Islamic Education. 56\% of the budget comes from pure rupiah; $36 \%$ comes from non-tax revenue, and $8 \%$ comes from government Sharia Security. A substantial amount of funds is one of the things required to achieve World Class University. For example, the University of Chicago spent two decades and more than $\$ 50$ million. By current value, it is equivalent to $\$ 500$ million (Altbach, 2003).

Tabel 1 Performance agreement of Rector of UIN Sunan Gunung Djati Bandung

Year 2019

\begin{tabular}{|c|c|c|c|}
\hline No & Program & Performance Indicators & Target \\
\hline \multirow[t]{4}{*}{1} & \multirow{4}{*}{$\begin{array}{l}\text { Increasing equity of } \\
\text { access to Islamic } \\
\text { higher education }\end{array}$} & Number of new students accepted & 5855 students \\
\hline & & Number of students who receive BIDIKMISI scholarship & 1125 students \\
\hline & & $\begin{array}{l}\text { Number of students who receive academic and } \\
\text { achievement scholarships }\end{array}$ & 184 students \\
\hline & & Number of students who receive tahfidz scholarship & 47 students \\
\hline \multirow[t]{10}{*}{2} & \multirow{10}{*}{$\begin{array}{l}\text { Increasing the quality } \\
\text { of services of Islamic } \\
\text { higher education } \\
\text { institution }\end{array}$} & Quality and the score of institution accreditation & A \\
\hline & & Percentage of programs that are accredited A & $45 \%$ \\
\hline & & Number of programs that are accredited A & 27 Programs \\
\hline & & Percentage of programs that are accredited B & $50 \%$ \\
\hline & & Number of programs that are accredited B & 28 Programs \\
\hline & & $\begin{array}{l}\text { Number of programs that implement Indonesian Nasional } \\
\text { Qualifications Framework }\end{array}$ & 60 Programs \\
\hline & & The average number of the semester to finish the study & 9 Semesters \\
\hline & & The average score of GPA & 3,4 \\
\hline & & Number of nationally accredited journals & 13 journals \\
\hline & & Number of journal database subscribed & 3 DataBases \\
\hline \multirow[t]{10}{*}{3} & \multirow{10}{*}{$\begin{array}{l}\text { Increasing the quality } \\
\text { of facilities and } \\
\text { infrastructures }\end{array}$} & $\begin{array}{l}\text { Number of the classroom in good condition (meeting } \\
\text { standard) }\end{array}$ & 250 classroom \\
\hline & & Number of the standard laboratory & 13 Laboratories \\
\hline & & Number of the book collection & 113000 exemplar \\
\hline & & Number of the e-book collection & 2150 titles \\
\hline & & Availability of e-library & Yes \\
\hline & & Number of rooms for student activities & 31 Rooms \\
\hline & & The ratio of workplace size per lecturers & $3 \mathrm{M}^{2}: 1$ \\
\hline & & The ratio of reading space size per librarian & $6 \mathrm{M}^{2}: 1$ \\
\hline & & $\begin{array}{l}\text { The number of standard facilities and infrastructures for } \\
\text { disabled faculty members and students }\end{array}$ & 6 rooms \\
\hline & & The ratio of praying space size per person & $0,6 \mathrm{M}^{2}: 1$ \\
\hline \multirow[t]{7}{*}{4} & \multirow{7}{*}{$\begin{array}{l}\text { Increasing the quality } \\
\text { and classification of } \\
\text { teaching and } \\
\text { educational staff in } \\
\text { Islamic higher } \\
\text { education institutions }\end{array}$} & The percentage of teaching staff with a Doctorate level & $43 \%$ \\
\hline & & Number of lecturers with a Doctorate level & 381 People \\
\hline & & Percentage of certified lecturers & $92 \%$ \\
\hline & & Number of certified lecturers & 735 People \\
\hline & & Number of Professors & 37 People \\
\hline & & $\begin{array}{l}\text { Number of educational staff that received a postgraduate } \\
\text { scholarship }\end{array}$ & - \\
\hline & & $\begin{array}{l}\text { Number of lecturers that participated in an international } \\
\text { scientific forum }\end{array}$ & 248 People \\
\hline
\end{tabular}


$5 \quad$ Increasing the quality of research result in Islamic higher education

Increasing relevance and competitiveness of Islamic higher education

Increasing institutional governance and authority of Islamic higher education
Number of certified educational staff (laboratory assistant, librarian, and archivist)

Number of research/study conducted

Number of publication in nationally accredited journals

Number of publication in internationally accredited journals

Number of intellectual property right registered

Number of nationally accredited journals in the university

The number of students that received a scholarship in

Islamic basic sciences

The number of students that participated in the industrial world.

Number of community services conducted

Percentage of graduates that directly gained employment after graduation

Number of research projects that cooperate with industry

Number of MoU with International institutions

Number of students that received gold medals in national and international level

The availability of a strategic plan

Percentage of output volume that reached the target in RKA-KL

Percentage of budget performance achievement in SMART-DJA application

Number of sops produced

Percentage of decrease in number that becomes findings by National Audit Board (BPK)

Percentage of increase in non-tax income in 2019

The number of funding partners in Islamic higher education from the government and industry.
3 People

400 pieces of

research

170 publication

140 publication

165 intellectual property rights

2 journals

57 students

2380 students

60 programs

$42 \%$

3 Documents

6 Institutions

20 People

Yes

$97 \%$

$95 \%$

160 SOP

$50 \%$

$17,89 \%$

9 Partners

*RKA-KL: Rencana Kerja dan Anggaran Kementrian dan Lembaga (Ministry and agency work plans and budgets)

Based on the 2019 condition, UIN Sunan Gunung Djati Bandung set the following targets (Table 2) to achieve world-class university status using QS Ranking. Based on Table 2, there are six targets of UIN Sunan Gunung Djati Bandung toward WCU. The targets are academic, employer reputation, citation per lecturer, lecturer student ratio, and, international student and lecturer. If the annual score increase is constantly, UIN Sunan Gunung Djati Bandung will meet 6 QS criteria by 2029. It will rank 500 ${ }^{\text {th }}$ Asia World University with score 23.

Table 2 Targets of UIN Sunan Gunung Djati Bandung for the next five years

\begin{tabular}{|c|c|c|c|c|c|c|c|}
\hline \multirow[t]{2}{*}{ Criteria } & \multirow[t]{2}{*}{ Main theme } & \multirow[t]{2}{*}{ Presentation } & \multicolumn{5}{|c|}{ Target (Year) } \\
\hline & & & 2019 & 2020 & 2021 & 2022 & 2023 \\
\hline \multirow{10}{*}{$\begin{array}{l}\text { Academic } \\
\text { Reputation }\end{array}$} & Academic & $40 \%$ & 1 & 2 & 3 & 5 & 10 \\
\hline & reputation & & Accredited A & Assessment & Accredited & Preparation & Preparation \\
\hline & score based & & by National & Registration & by AUN- & for ASIIN & and ASIIN \\
\hline & on an & & Higher & by AUN- & QA and & visitation & visitation \\
\hline & academic & & Education & QA & registration & & \\
\hline & survey by & & Accreditation & & for ASIIN & & \\
\hline & academic & & Agency & & membership & & \\
\hline & experts & & (BAN-PT) & & & & \\
\hline & & & Registration & Presentation & ASEA & Participation & Benefits \\
\hline & Database & & ASEA & ASEA & UNINET & ASEA & $\begin{array}{l}\text { from } \\
\text { ASEA }\end{array}$ \\
\hline
\end{tabular}




\begin{tabular}{|c|c|c|c|c|c|c|c|}
\hline \multirow[t]{3}{*}{ Criteria } & \multirow[t]{3}{*}{ Main theme } & \multirow[t]{2}{*}{ Presentation } & \multicolumn{5}{|c|}{ Target (Year) } \\
\hline & & & 2019 & 2020 & 2021 & 2022 & 2023 \\
\hline & & & $\begin{array}{l}\text { UNINET and } \\
\text { NUNI }\end{array}$ & $\begin{array}{l}\text { UNINET } \\
\text { and NUNI }\end{array}$ & $\begin{array}{l}\text { and NUNI } \\
\text { membership }\end{array}$ & $\begin{array}{l}\text { UNINET } \\
\text { and NUNI }\end{array}$ & $\begin{array}{l}\text { UNINET } \\
\text { and NUNI }\end{array}$ \\
\hline $\begin{array}{l}\text { Employer } \\
\text { reputation }\end{array}$ & $\begin{array}{l}\text { Employer } \\
\text { reputation } \\
\text { score based } \\
\text { on employer } \\
\text { survey on } \\
\text { QS database } \\
\text { by } \\
\text { considering } \\
\text { the quality } \\
\text { of the } \\
\text { graduates }\end{array}$ & $10 \%$ & $\begin{array}{l}4 \\
(42 \%)\end{array}$ & $\begin{array}{l}10 \\
(45 \%)\end{array}$ & $\begin{array}{l}11 \\
(50 \%)\end{array}$ & $\begin{array}{l}15 \\
(52 \%)\end{array}$ & $\begin{array}{l}20 \\
(60 \%)\end{array}$ \\
\hline $\begin{array}{l}\text { Citation per } \\
\text { lecturer }\end{array}$ & $\begin{array}{l}\text { Citation } \\
\text { level per } \\
\text { lecturer by } \\
\text { Thomson } \\
\text { Scientific or } \\
\text { Scopus }\end{array}$ & $20 \%$ & $\begin{array}{l}2 \\
(170 \\
\text { citations) }\end{array}$ & $\begin{array}{l}8 \\
\text { (200 } \\
\text { citations) }\end{array}$ & $\begin{array}{l}10 \\
(250 \\
\text { citations })\end{array}$ & $\begin{array}{l}13 \\
(300 \\
\text { citations) }\end{array}$ & $\begin{array}{l}15 \\
(350 \\
\text { citations })\end{array}$ \\
\hline $\begin{array}{l}\text { Lecturer } \\
\text { students } \\
\text { ratio }\end{array}$ & $\begin{array}{l}\text { The ratio of } \\
\text { lecturers } \\
\text { and students }\end{array}$ & $20 \%$ & $\begin{array}{l}4 \\
(1: 40)\end{array}$ & $\begin{array}{l}7 \\
(1: 38)\end{array}$ & $\begin{array}{l}12 \\
(1: 36)\end{array}$ & $\begin{array}{l}15 \\
(1: 34)\end{array}$ & $\begin{array}{l}18 \\
(1: 32)\end{array}$ \\
\hline $\begin{array}{l}\text { International } \\
\text { students }\end{array}$ & $\begin{array}{l}\text { Number of } \\
\text { international } \\
\text { students }\end{array}$ & $5 \%$ & $\begin{array}{l}5 \\
\text { (167 } \\
\text { students) }\end{array}$ & $\begin{array}{l}8 \\
\text { (175 } \\
\text { students) }\end{array}$ & $\begin{array}{l}10 \\
(185 \\
\text { students) }\end{array}$ & $\begin{array}{l}12 \\
\text { (195 } \\
\text { students) }\end{array}$ & $\begin{array}{l}15 \\
\text { (205 } \\
\text { students) }\end{array}$ \\
\hline $\begin{array}{l}\text { International } \\
\text { lecturers }\end{array}$ & $\begin{array}{l}\text { Number of } \\
\text { international } \\
\text { visiting } \\
\text { lecturers } \\
\text { and } \\
\text { researchers. }\end{array}$ & $5 \%$ & $\begin{array}{l}1 \\
(2)\end{array}$ & $\begin{array}{l}2 \\
(3)\end{array}$ & $\begin{array}{l}3 \\
(4)\end{array}$ & $\begin{array}{l}8 \\
(5)\end{array}$ & $\begin{array}{l}10 \\
(6)\end{array}$ \\
\hline Skor total & & & 2,3 & 5,3 & 7,35 & 10,1 & 13,85 \\
\hline
\end{tabular}

*AUN-QA: ASEAN University Network; ASIIN: Accreditation Agency for Degree Programs; BAN-PT: Badan Akreditasi Nasional Perguruan Tinggi/ National Higher Education Accreditation Agency; ASEA-UNINET: The ASEAN European Academic University Network; NUNI: Nationwide University Network in Indonesia

By browsing to QS Asia University Ranking Page (https://www.topuniversities.com), we can find that 22 universities in Indonesia are on the list of QS Asia University Ranking (by 19 June 2019). Furthermore, from the 22 universities, nine are on the list of QS World University Ranking. Among them are located in West Java, such as IPB, Padjajaran University, and ITB. With effort by UIN Sunan Gunung Djati Bandung to be a world class university, the number of Indonesian universities listed on the QS World University, especially in West Java, will grow. In achieving the target by 2029, UIN Sunan Gunung Djati tries to be consistent with its goal. However, there are still several challenges faced by LPTK. Chiefs among them are B accredited programs, limitation of international visiting professors, low qualification of lecturers, and lecturer language skills. Nevertheless, these issues are being tackled through certain programs by the university.

An increase in world-class university ranking lists can be realized in several ways. For example, Achsan (2014) suggested that conducting online document collaboration among higher education institutions in Indonesia can support it. Further, Setiawan (2009) believes that strategic planning on information systems in higher education institutions can help it to have the quality of WCU. Therefore, UIN Sunan Gunung Djati Bandung can implement such strategies to achieve its goal. Another way can be achieved via research publication (Tie, 2012), and the presence and mobility of international students (Findlay et al., 2012).

\section{B. Recommended Priority Programs}


After formulating indicators from WCU, the next step for UIN should is to integrate them into annual programs. These indicators will be realized through several recommended priority programs in the period 20192023, as seen in Table 3.

Table 3. Recommendation of priority programs for UIN Sunan Gunung Djati Bandung toward WCU Period 20192023

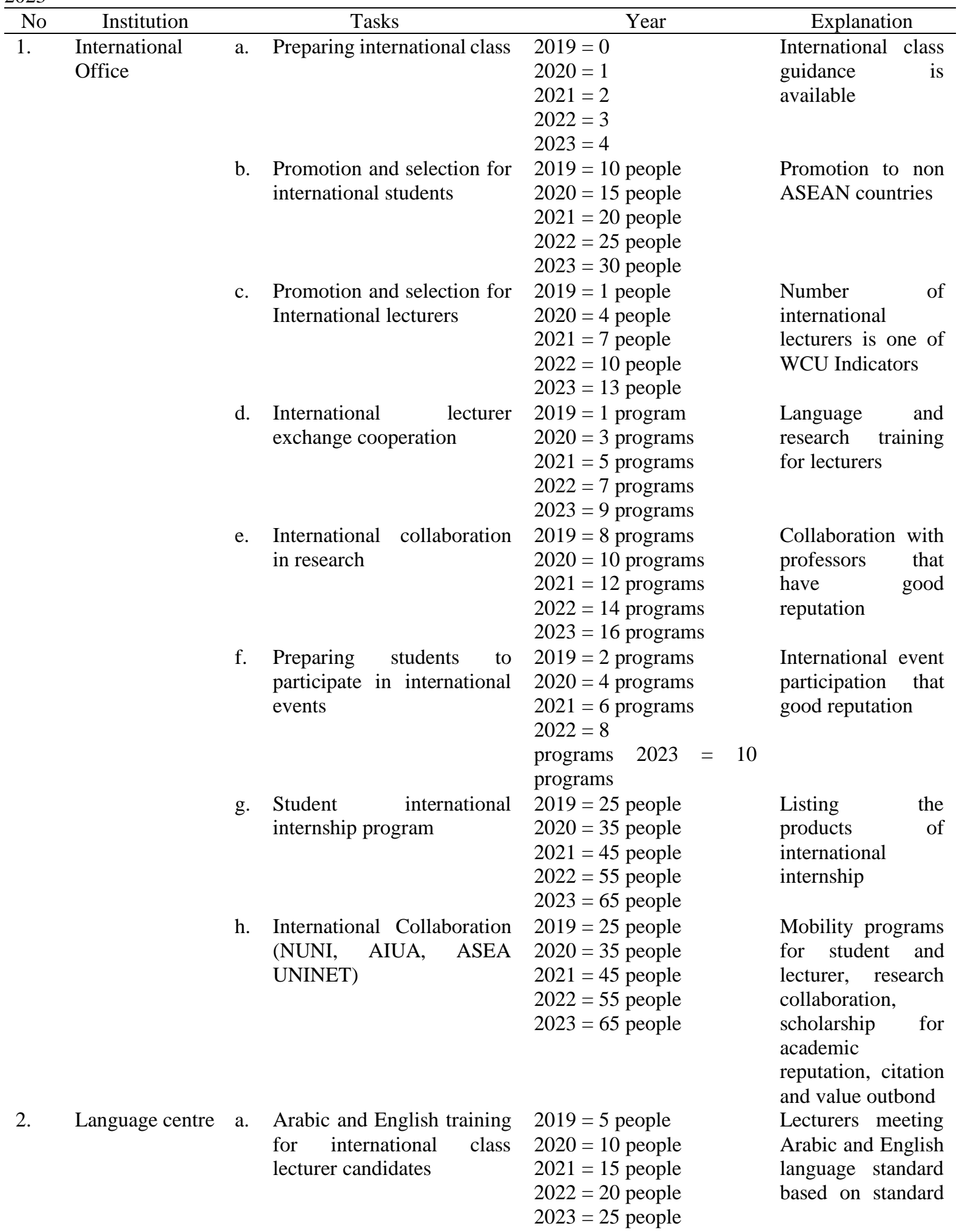




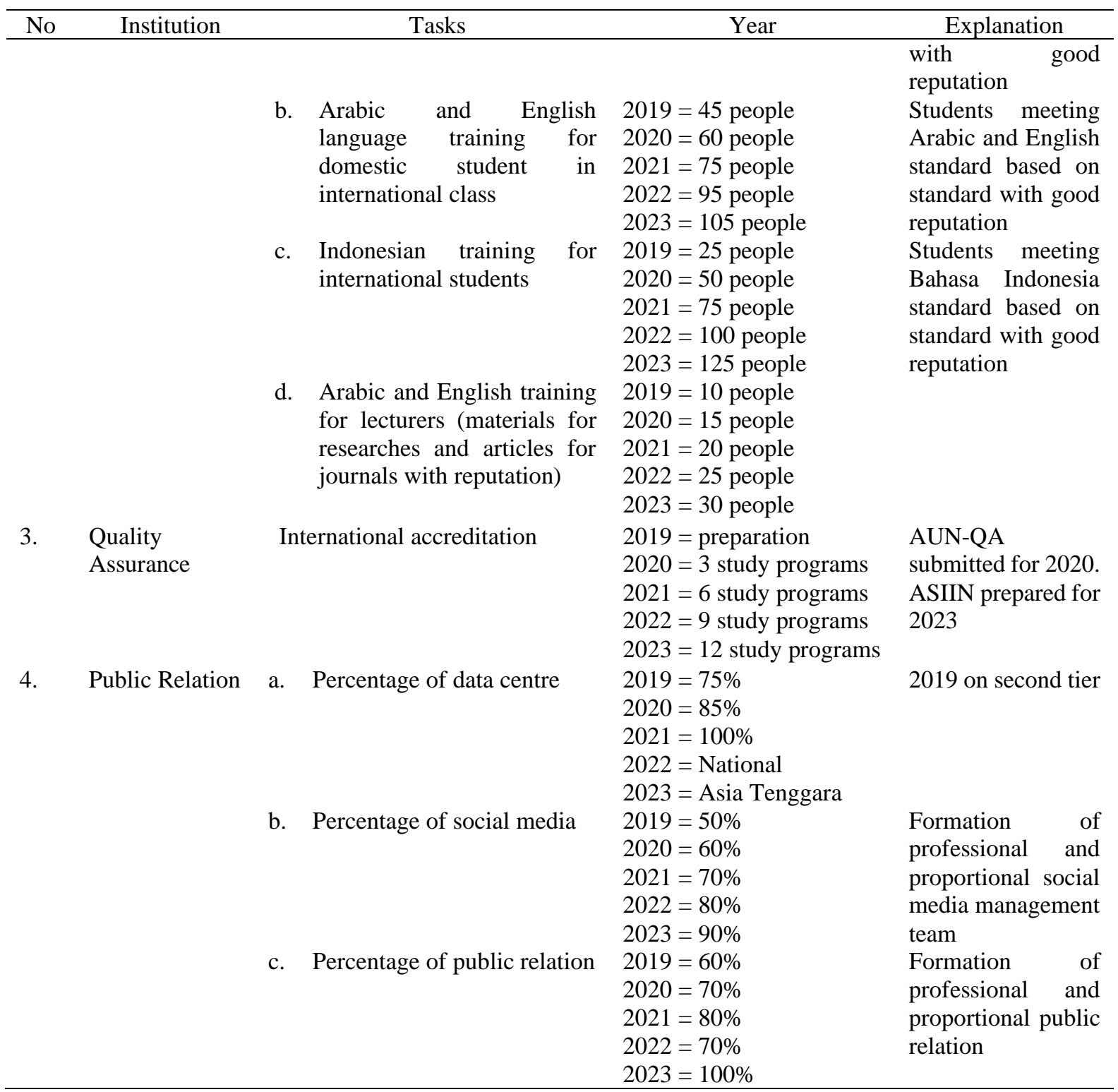

Table 3 explains that the policy of priority programs toward WCU is applied to part within the institution with their own planned annual tasks and targets. International office, language center, quality assurance, and public relations can help to achieve UIN Sunan Gunung Djati's targets.. Moreover, aspects of language center, quality assurance, and public relation - with all the components of target - are increasing from year to year. Hopefully, these targets can be achieved by reviewing the current conditions. In the university wich already carry World Class University there are centainly more institution in them.

The first institution is the international office. The presence of international office not only in formal education institution, but non formal educational institution has international office, even the institution is independent because this institution is an investment and is considered to have the production of financial space (Lizieri \& Pain, 2014). The second institution is language center. The presence of language center can help local and international of students and lecturers for more knowing about several language. In language center of UIN is Arabic and English training for international class student and lecturer candidates, Bahasa Indonesia training for international students and arabic and anglish training for lecturers (materials for researches and articles for journals with reputation). The third institution is quality assurance. This institution have task is international accreditation. Global competitiveness in higher education is encourage of institution to seek international accreditation such as the country of Taiwan (Hou, 2011). If the international accreditation can improve of quality in higher education so in order to evaluate and improve quality in higher education, a model of value in higher education that connects 
quality with relevance, access and investment is necessary (Blanco-Ramírez, \& Berger, 2014) and this can be done by UIN Sunan Gunung Djati Bandung to improve its quality. And the last institution is public relation with three task (data center, social media and public relation). Information relating to everything of UIN Sunan Gunung Djati Bandung summarized in data center, published through social media and the search for professionals engaged in the filed of public relation. The selection of social media for delivering of information is one of the right way. Social media uses in higher education not only use as tool for teaching, but can role as learning and sharing of information (Test, 2013).

These priority programs must become common commitments so they can become realized. On a side note, the psychology part is important in this plan to support the development of World Class University. Psychology can help prepare future leaders that are highly committed to the institution (Ritz \& Waldner, 2011). Furthermore, it can also help lecturers to achieve their potential. It also can partake in human resource management and help in the selection of new lecturers and staffs (Seniati, 2009).

\section{CONCLUSION AND RECOMMENDATION}

By focusing on priority policies and programs above, UIN Sunan Gunung Djati Bandung is expected to meet the standard criteria of QS World University Ranking by 2029. Therefore, this plan must become common will and effort among the academic community in UIN Sunan Gunung Djati Bandung without exception. Becoming World Class University is an intention and determination that is not making it up and uppearing suddenly. Morevoer, several benefit from this research is 1) Practically, this research can measure the readiness of UIN Sunan Gunung Djati Bandung in reaching WCU with the QS Ranking indicator, 2) Managerially, this research can map units in the UIN Sunan Gunung Djati Bandung environment to prepare themselves to fit the predetermined targets and 3) Socially, become a benchmark for other campuses to achieve WCU according to the QS Ranking indicator. In the future, the researchers recommend further research and the use of different data collection methods and methods to produce different and more comprehensive data.

\section{REFERENCES}

Agung, I., and Santosa, A. (2017) Dinamika LPTK Menuju Perguruan Tinggi Kelas Dunia (World Class University/WCU), Perspektif Ilmu Pendidikan, Vol 31 No 1, pp.43-54.

Achsan, H. T. Y. (2014) Menaikkan Peringkat Global Perguruan Tinggi Indonesia Melalui Kolaborasi Dokumen Online, In Conference: KNSI.

Alperin, J. P. (2013). Brazil's exception to the world-class university movement. Quality in higher education, Vol 19 No 2, pp.158-172. https://doi.org/10.1080/13538322.2013.802573

Altbach, P. G. (2003) The costs and benefits of world-class universities, International Higher Education, (33).

Altbach, P. G. (2004) Higher education crosses borders, Change, Vol 36 No 2, pp.18-24.

Altbach, P. and Balan, J. (Eds). (2007) World Class Worldwide: transforming research universities in Asia and Latin America. Baltimore: Johns Hopkins University Press.

Aula, H. M., and Tienari, J. (2011) Becoming "world-class"? Reputation-building in a university merger. Critical perspectives on international business, Vol 7 No 1, pp.7-29.

Blanco-Ramírez, G. and B. Berger, J. (2014) Rankings, accreditation, and the international quest for quality: Organizing an approach to value in higher education, Quality Assurance in Education, Vol. 22 No. 1, pp. 88-104. https://doi.org/10.1108/QAE-07-2013-0031

Byun, K., Jon, J. E., and Kim, D. (2013) Quest for building world-class universities in South Korea: Outcomes and consequences, Higher Education, Vol 65 No 5, pp.645-659.

Deem R, Ho M and Lucas L. (2008) Transforming higher education in whose image? Exploring the concept of the world class university in Europe and Asia, Higher Education Policy, Vol 21, pp.83-97.

Findlay, A. M., King, R., Smith, F. M., Geddes, A., \& Skeldon, R. (2012) World class? An investigation of globalisation, difference and international student mobility, Transactions of the Institute of British Geographers, Vol 37 No 1, pp.118-131.

Hou, A.Y. (2011) Quality assurance at a distance: international accreditation in Taiwan higher education. High Educ Vol 61, pp.179-191. https://doi.org/10.1007/s10734-010-9331-9

Lizieri, C., \& Pain, K. (2014) International office investment in global cities: the production of financial space and systemic risk, Regional Studies, Vol 48 No 3, pp.439-455.

Marginson, S. (2011) Higher education and public good, Higher education quarterly, Vol 65 No 4, pp.411-433. 
Top Universities. (2019) QS Asia University Ranking, Retrivied from https://www.topuniversities.com/university-rankings/asian-university-rankings/2019. (Accessed 2019, Juni 19)

Ramaprasad, A. (2011) Envisioning a world-class university system for India, International Journal of Technology Management \& Sustainable Development, Vol 10 No 1, pp.45-54.

Ritz, A., and Waldner, C. (2011) Competing for future leaders: A study of attractiveness of public sector organizations to potential job applicants, Review of Public Personnel Administration, Vol 31 No 3, pp.291316.

Salmi, J. (2009) The Challenge of Establishing World-Class Universities, Washington, DC: The World Bank.

Seniati, A. N. L. (2009) Peran psikologi dalam mengembangkan universitas kelas dunia, Fakultas Psikologi, Universitas Indonesia: Depok, Indonesia.

Setiawan, E. B. (2009) Perancangan Strategis Sistem Informasi IT TELKOM untuk menuju World Class University, Paper presented at Seminar Nasional Aplikasi Teknologi (SNATI) (C2009 Yogyakarta

Shin, J. C., and Kehm, B. M. (Eds.). (2012) Institutionalization of world-class university in global competition. Springer Science \& Business Media: New York.

Supradono, B. (2010) Strategi meningkatkan kinerja web universitas Muhammadiyah semarang menuju peringkat webometrics, Media Elektrika, Vol 3 No 1, pp.49-63.

Suyanti, E. (2011) Strategi Internasionalisasi Dalam Bidang Penelitian Pada Universitas Indonesia Dan Institut Pertanian Bogor, Jurnal Manajemen Pendidikan, Vol 2 No 1, pp.10-21

Tayeb, O., Zahed, A., and Ritzen, J, (2016) Becoming a World-Class University, The Case of King Abdulaziz. University (pp. 1-19). Springer, Cham.

Tess, P. A. (2013) The role of social media in higher education classes (real and virtual)-A literature review. Computers in human behavior, Vol 29 No 5, pp.A60-A68.

Tie, F. H. (2012) Research publication as a strategy to improve international academic ranking, International Journal of Leadership in Education, Vol 15 No 4, pp.437-450.

Wieczorek, A. J., \& Hekkert, M. P. (2012). Systemic instruments for systemic innovation problems: A framework for policy makers and innovation scholars. Science and public policy, Vol 39 No 1, pp.74-87. https://doi.org/10.1093/scipol/scr008

Yang, R., Welch, A. (2012). A world-class university in China? The case of Tsinghua. High Educ Vol 63, pp.645666. https://doi.org/10.1007/s10734-011-9465-4

Yudkevich, M., Altbach, P. G., \& Rumbley, L. E. (2015) Global university rankings: The "Olympic Games" of higher education?, Prospects, Vol 45 No 4, pp.411-419. 